Плодоводство и виноградарство Юга России № 72(6), 2021 г.

УДК 634.852(470.61)

DOI 10.30679/2219-5335-2021-6-72-18-31

ПЕРСПЕКТИВНЫЙ

АБОРИГЕННЫЙ

СОРТ ВИНОГРАДА

КОСОРОТОВСКИЙ

В НИЖНЕМ ПРИДОНЬЕ

Ганич Валентина Алексеевна

канд. с.-х. наук

ведущий научный сотрудник

лаборатории ампелографии

e-mail: ganich1970@yandex.ru

Наумова Людмила Георгиевна

канд. с.-х. наук

ведущий научный сотрудник

лаборатории ампелографии

e-mail: LGnaumova@yandex.ru

Всероссийский научно-исследовательский институт виноградарства и виноделия имени Я.И. Потапенко - филиал

Федерального государственного

бюджетного научного учреждения

«Федеральный Ростовский

аграрный научный центр»,

Новочеркасск, Россия

Исследования проводили в 2015-2020 гг. на Донской ампелографической коллекции имени Я.И. Потапенко (г. Новочеркасск, Ростовской обл.). Объектом исследования был аборигенный донской сорт

Косоротовски, контролем - сорт

Пухляковский. По морфологическим признакам и биологическим свойствам Косоротовский относится к сортам бассейна Черного моря. Изучение сортов винограда проводили с использованием общепринятых в виноградарстве методик и ГОСТов. Сорта изучались в укрывной, привитой культуре на подвое Кобер 5ББ. Схема посадки кустов 3,0 x 1,5 м.

По средним данным агробиологических
UDC 634.852(470.61)

DOI 10.30679/2219-5335-2021-6-72-18-31

\section{PERSPECTIVE NATIVE GRAPE VARIETY \\ KOSOROTOVSKIY UNDER THE CONDITIONS OF LOWER DON REGION}

\author{
Ganich Valentina Alekseevna \\ Cand. Agr. Sci. \\ Leading Research Associate \\ of Laboratory of Ampelographic \\ e-mail: ganich1970@yandex.ru
}

Naumova Lyudmila Georgievna

Cand. Agr. Sci.

Leading Research Associate

of Laboratory of Ampelographic

e-mail: LGnaumova@yandex.ru

\author{
All-Russian Research \\ Ya.I. Potapenko Institute \\ for Viticulture and Winemaking - \\ Branch of the Federal State \\ Budget Scientific Institution \\ «Federal Rostov Agricultural \\ Research Center», \\ Novocherkassk, Russia
}

The research was carried out in 2015-2020 at the Don ampelographic collection named after Ya.I. Potapenko (Novocherkassk, Rostov region). The object of the research was a native Don grape variety Kosorotovskiy. The Pukhlyakovskiy variety was the control. According to morphological characteristics and biological properties, Kosorotovskiy belongs to the varieties of the Black Sea basin. The study of grape varieties was carried out using methods generally accepted in viticulture and National Standards. The varieties were studied in a covered and grafted culture on the Kober 5BB rootstock. The planting scheme of bushes was $3.0 \times 1.5 \mathrm{~m}$. According to the average 
учетов и наблюдений сорт Косоротовский имел 59,6 \% распустившихся глазков, 48,5 \% плодоносных побегов, коэффициент плодоношения - 0,7, средняя масса грозди была 297 г, урожайность 5,2 кг/куст.

По данным механического анализа грозди содержание в процентах к массе грозди: сока 77,7; гребней 3,3; выжимок 15,0; семян 4,0. По результатам увологической оценки: размеры грозди (длина 16,8 cм, ширина 9,7 см), размеры ягоды (длина 18,4 мм, ширина 16,3 мм), средняя масса ягоды 3,3 г, сахаристость сока ягод 20,2 г/100 $\mathrm{cm}^{3}$ при титруемой кислотности 7,5 г/дм ${ }^{3}$. Сорт Косоротовский технологичен, быстро осветляется, не требует дополнительных приемов при переработке. Вино прозрачное, с блеском, соломенного цвета с зеленоватым оттенком. Аромат чистый, достаточно сформировавшийся, с легкими цветочно-фруктовыми тонами. Вкус гармоничный, полный. Средняя дегустационная оценка вина была 8,6 балла (на уровне контрольного сорта Пухляковский). По результатам проведенного изучения агробиологических, технологических, увологических и хозяйственно-ценных свойств сорт Косоротовский не уступает контрольному сорту Пухляковский и может быть рекомендован для включения в сортимент виноградных насаждений Нижнего Придонья. Рекомендуется использовать этот сорт в селекции для генетического улучшения белых технических сортов винограда как источник ценных хозяйственно-биологических и технологических свойств для высококачественного виноделия.

Ключевые слова: ВИНОГРАД, АБОРИГЕННЫЙ СОРТ, АМПЕЛОГРАФИЧЕСКАЯ КОЛЛЕКЦИЯ, УРОЖАЙНОСТЬ, УВОЛОГИЧЕСКАЯ ХАРАКТЕРИСТИКА data of agrobiological records and observations, the Kosorotovskiy variety had $59.6 \%$ of blossoming buds, $48.5 \%$ of fruiting shoots, the fruitfullness coefficient was 0.7 , the average mass of a bunch was $297 \mathrm{~g}$, yield capacity $-5.2 \mathrm{~kg} / \mathrm{bush}$. According to the mechanical analysis of the bunch, the percentage content to the bunch weight was following: juice $77.7 \%$; stems - $3.3 \%$; pomace - $15.0 \%$; seeds $-4.0 \%$. According to the results of uvological assessment: the size of a bunch is $16.8 \mathrm{~cm}$ long, $9.7 \mathrm{~cm}$ wide, the size of the berry is $18.4 \mathrm{~mm}$ long, $16.3 \mathrm{~mm}$ wide, the average weight of a berry $-3.3 \mathrm{~g}$, the sugar content of the berry juice $20.2 \mathrm{~g} / 100 \mathrm{~cm}^{3}$ with a titratable acidity of $7.5 \mathrm{~g} / \mathrm{dm}^{3}$. The Kosorotovskiy variety is technologically advanced, quickly clarified, does not require additional processing techniques. The wine is transparent, shiny, straw-colored with a greenish tint. The aroma is clean, well-formed, with light floral and fruity tones. The taste is full and harmonious. The average wine tasting score was 8.6 points (at the level of the control variety Pukhlyakovskiy). According to the results of the study of agrobiological, technological, ecological and economically valuable properties, the Kosorotovskiy variety is not inferior to the control variety Pukhlyakovskiy and can be recommended for inclusion in the assortment of grape plantations of the Lower Don region. It is also recommended to use this variety in breeding for the genetic improvement of white technical grape varieties as a source of valuable economic, biological and technological properties for high-quality winemaking.

Key words: GRAPE, NATIVE VARIETY, AMPELOGRAPHIC COLLECTION, YIELD CAPACITY, UVOLOGICAL CHARACTERISTIC 
Введение. Обновление и совершенствование сортимента винограда является беспрерывным и естественным эволюционным процессом. На нынешнем этапе особое внимание производственников и селекционеров стали привлекать местные аборигенные сорта винограда [1].

Аборигенный сорт винограда (от латинского aborigines, от ab origine - от начала) - местный виноград какого-либо района, края, региона. Термин «аборигенный виноград» чаще применяется в отношении культурных сортов, но также за аборигенный сорт винограда принимается сорт, который произошел от диких видов или их форм, произрастающих в данной местности [2].

В древних районах виноградарства (Закавказье и Средняя Азия) сортимент создавался в основном путем отбора дикорастущего винограда. Наиболее тесная связь между дикорастущим виноградом и аборигенными сортами установлена в Западной Грузии, Азербайджане и прилегающих районах Армении, а также Туркмении (Западный Копет-Даг). Этим районам свойственны определенные, но различные в каждом месте, типы дикорастущего и культивируемого винограда. В Узбекистане и Таджикистане, где сортимент сложился в основном из столовых сортов, завезенных из Ирана, нет почти никакой связи между дикорастущим и культурным виноградом. Но в результате неоднократного посева семян и длительного искусственного отбора образовались местные высококачественные столовые и изюмные сорта. В Дагестане, в районе Астрахани, на Дону, на Северном Кавказе, Крыму и Молдавии местный сортимент может быть назван условно аборигенным. Многие сорта сохранились здесь с древних времен, но произошли они, главным образом, не от местного дикого винограда, а были завезены древними завоевателями-колонистами (греками, генуэзцами, турками, татарами). Во всех районах, кроме того, имеются сорта, сравнительно недавно завезенные из Западной Европы [3-5]. 
Плодоводство и виноградарство Юга России № 72(6), 2021 г.

Аборигенным считается местный сортимент винограда региона, созданный на основе длительной народной селекции, или путем отбора из дикорастущего винограда.

Многочисленность и специфичность донского сортимента аборигенных сортов - одни из наиболее важных свидетельств многовековой культуры винограда на Дону. Сорта и формы винограда с разнообразными ягодами по величине, окраске, вкусовым качествам могли возникнуть только в результате его возделывания в течение многих сотен лет. Основным условием, способствующим успешному возделыванию винограда, является благоприятный климатический фактор [6].

Десятки веков скрывают от нас начало виноградарства на Дону. Археологические находки в пределах Ростовской области говорят о том, что виноградарство и виноделие было на Дону ещё в I-IV веках нашей эры, а некоторые авторы склонны относить начало виноградарства к VII веку до нашей эры. Страбон указывал, что виноградники были у входа в ПалусМеотиду, то есть в устье реки Дон, это относится ко времени около 2-2,5 тыс. лет назад [7].

По вопросу происхождения донских аборигенных сортов есть мнение, что родиной их предположительно является Европа: одни сорта могли быть завезены из Франции, Германии, другие - с Балканского полуострова [8]. Некоторые сорта были завезены из Крыма и получили на Дону местные названия: Ладанный (Мускат белый), Дурман (Мускат константинопольский), Буланый (Джеват кара), Долгий (Кокур белый). Из завезённых сортов распространение получили наиболее адаптированные к местным условиям. Ряд сортов появился путем отбора из самовсходов в результате свободного опыления. На старинных донских виноградниках насчитывалось более 40 различных сортов винограда. Лишь о немногих из них можно сказать, более или менее определенно, когда и при каких обстоятельствах они начали культивироваться на Дону [9]. 
Общее происхождение ряда дагестанских и донских сортов было доказано исследованиями морфологических признаков [6, 9]. Давние взаимосвязи между этими регионами подтверждаются историческими сведениями. Так, к донским сортам цимлянской группы относят по морфотипу и некоторые сорта Дагестана (Чингири кара, Бор кара, Гок ала).

Для идентификации генотипов аборигенных сортов пользуются методом микросателлитных маркеров (SSR). Такого рода исследования могут дополнять ампелографические характеристики и, как правило, используются в качестве продвинутого молекулярного инструмента для управления в рамках коллекции генетических ресурсов Vitis, таких как идентификация и различение генотипов, изучение генетического разнообразия, создание коллекции, изучение родословной и верификация [10-21].

В настоящее время в мире возрос интерес к изучению местных сортов винограда.

Цель исследований - изучение агробиологических, технологических и увологических показателей аборигенного сорта винограда Косоротовский в регионе происхождения.

Объекты и методы исследований. На Донской ампелографической коллекции ВНИИВиВ им. Я.И. Потапенко (г. Новочеркасск, Россия) в 2015-2020 гг. проведено изучение аборигенного донского сорта винограда Косоротовский, в качестве контроля - сорт Пухляковский. Сорта изучались в укрывной, привитой культуре на подвое Кобер 5ББ. Схема посадки кустов 3,0 х 1,5 м. Формировка кустов длиннорукавная. Культура неполивная. Грунтовые воды залегают глубоко и не оказывают влияния на развитие виноградных кустов. Технология возделывания виноградников общепринятая для северной зоны промышленного виноградарства РФ.

Изучение сортов винограда проводили с использованием общеустановленных в виноградарстве методик и ГОСТов. Сахаристость сока ягод определяли по ГОСТ 27198-87, титруемую кислотность - 
ГОСТ 32114-2013. Образцы виноматериалов готовились в лаборатории технологии виноделия в условиях микровиноделия по классической технологии приготовления столовых сухих белых вин. На закрытой научной дегустации была проведена оценка образцов вин дегустационной комиссией, утвержденной приказом директора, в соответствии с ГОСТ 32051-2013.

Сорт Косоротовский встречался на старых виноградниках Дона повсеместно, но особенно часто в Константиновском и Семикаракорском районах. Некоторые авторы считают, что свое название сорт получил по фамилии казака Косоротова. По морфологическим признакам и биологическим свойствам относится к Восточно-Кавказской подгруппе сортов бассейна Черного моря [22].

По предположению М.А. Лазаревского, сорт Косоротовский является местным сеянцем, возникшим от естественного скрещивания сортов Пухляковский и Белый круглый (Плавай).

При установлении происхождения сортов винограда народной селекции немаловажное значение имеют методы их идентификации. Международной организацией винограда и вина (MOBB) разработана унифицированная система описания сортов винограда. По нашему мнению, наиболее ценными при установлении происхождения сортов винограда являются основные признаки листьев, при формировании которых практически исключено воздействие искусственного отбора. В связи с этим были проанализированы основные признаки листьев у сортов винограда, которые предположительно являются естественными сеянцами сорта Пухляковский. Проведя промеры листьев (в соответствии с методикой МOBВ) установили, что по величине и форме листьев и соответственно длине главных жилок сорт Косоротовский оказался ближе к предполагаемому отцовскому сорту Плавай (Белый круглый) [6]. 
Кластерный анализ на основе данных фингерпринтинга по 6 микросателлитным локусам позволил сделать заключение, подтверждающее предположение о происхождении сорта Косоротовский от сорта Пухляковский [23]. Таким образом, выполненные промеры листьев и генетический анализ сорта Косоротовский подтверждают предположение М.А. Лазаревского о происхождении этого сорта.

Описание коронки молодого побега. Первый лист молодого побега сверху имеет довольно густое паутинистое опушение, особенно в углублениях жилок; второй - только редкие паутинистые волоски. На нижней поверхности первый-третий листья покрыты густым белым войлочным опушением. Ниже расположенные листья имеют более редкое паутинистое опушение. У молодых листьев красно-оранжевый оттенок, сильно меняющий свою интенсивность. Побег винно-красный (рис. 1) [22].

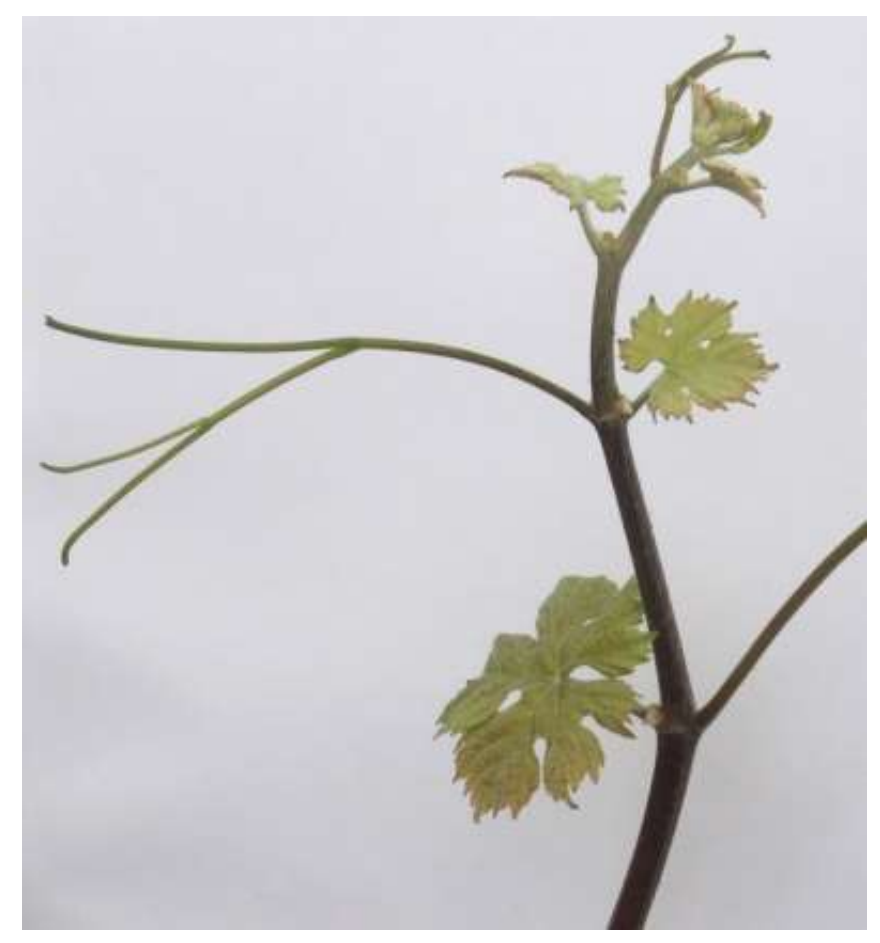

Рис. 1. Коронка молодого побега сорта Косоротовский

Сформировавшиеся листья средние и большие, грубые, воронковидно-желобчатые, от почти цельных до глубоко рассеченных, пятилопаст- 
ные, с широкой, тупой средней лопастью. Сверху сильно сетчатоморщинистые, снизу с густым паутинистым опушением и со щетинками на жилках. Верхние вырезки то мелкие в виде входящих углов, то средней глубины и глубокие, закрытые с овальными или яйцевидными просветами, реже открытые, лировидные. Нижние вырезки - едва намеченные в виде входящих углов или средней глубины, лировидные. Черешковая выемка закрытая с глубоко налегающими нижними лопастями с небольшим эллиптическим просветом и острым дном. Зубцы на концах лопастей крупные, остро треугольные. Краевые зубчики также острые, со слабовыпуклыми сторонами [22].

Цветки обоеполые. Грозди средние и большие (длина до 18-20 см), конические, часто с большим крылом, плотные и средней плотности (рис. 2). Ягоды средние и сравнительно крупные (длина 20,2 мм, ширина 17,6 мм, средняя масса 3,2-4,3 г) овальные, зеленовато-белые, при полной зрелости желтоватые. Кожица средней толщины, довольно прочная. Мякоть сочная, слегка мясистая. Вкус обыкновенный, приятный.

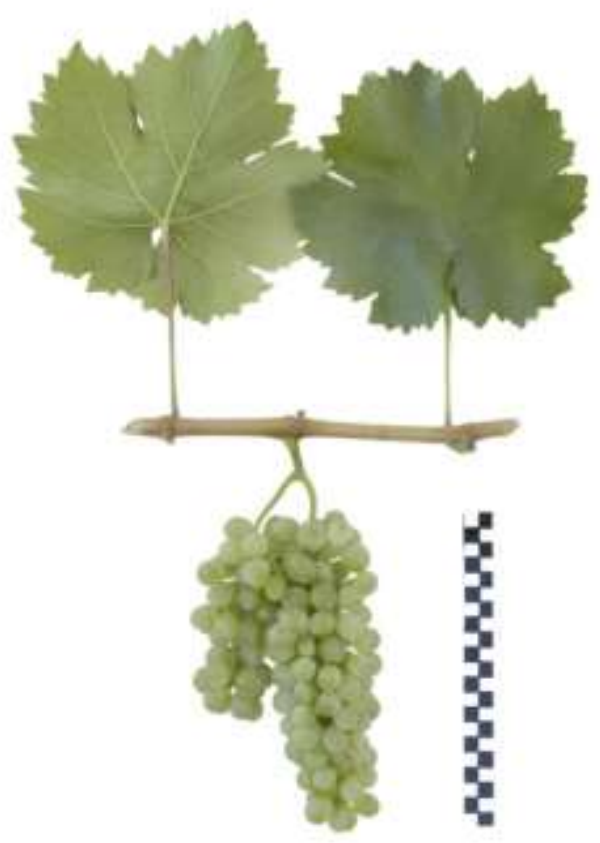

Рис. 2. Ампелоснимок грозди сорта Косоротовский

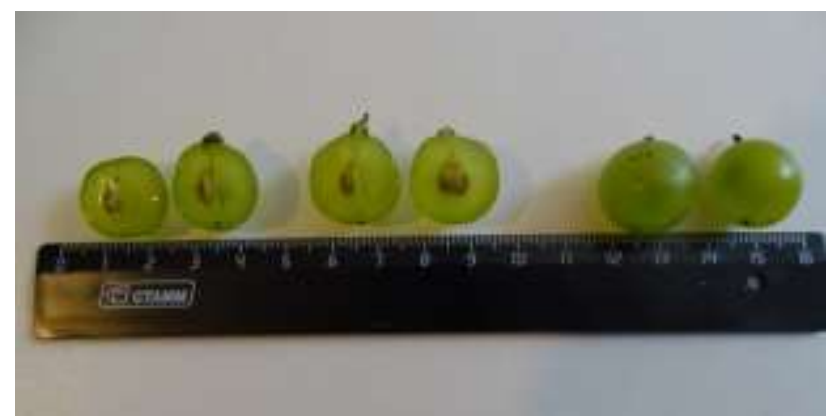

Рис. 3. Ягоды сорта Косоротовский 
Плодоводство и виноградарство Юга России № 72(6), 2021 г.

Косоротовский издавна считался на Дону столовым сортом для местного потребления, так как не выдерживает дальних перевозок. Однако исследования показали, что из урожая этого сорта можно получать столовые вина красивой окраски, легкие, гармоничные, с плодовым ароматом, а также хорошие виноматериалы для шампанского.

Обсужндене результатов. По данным агробиологических учетов в среднем за годы исследований сорт Косоротовский незначительно уступает контрольному сорту Пухляковский по количеству распустившихся глазков, проценту плодоносных побегов и коэффициенту плодоношения (табл. 1).

Таблица 1 - Агробиологические и хозяйственно ценные признаки изучаемых сортов (среднее за 2015-2020 гг.)

\begin{tabular}{|c|c|c|c|c|c|c|c|}
\hline \multirow[b]{2}{*}{ Название сорта } & \multirow{2}{*}{ 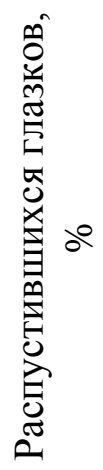 } & \multirow{2}{*}{ 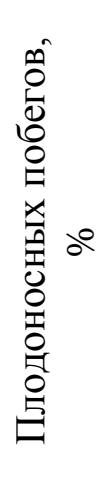 } & \multirow{2}{*}{ 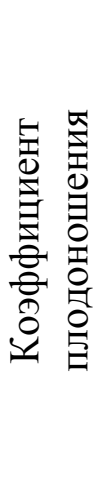 } & \multirow{2}{*}{ 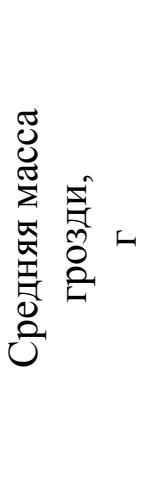 } & \multirow{2}{*}{ 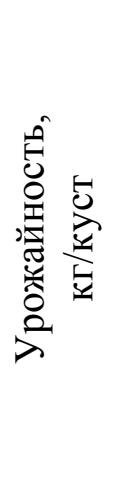 } & \multicolumn{2}{|c|}{$\begin{array}{c}\text { От начала распускания } \\
\text { почек до полной } \\
\text { зрелости ягод }\end{array}$} \\
\hline & & & & & & 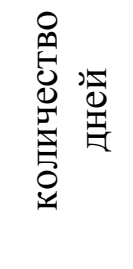 & 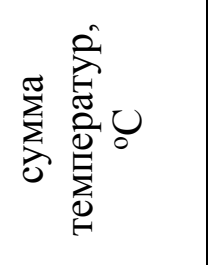 \\
\hline Косоротовский & 59,6 & 48,5 & 0,7 & 297 & 5,2 & 140 & 3136 \\
\hline Пухляковский & 69,3 & 56,0 & 0,8 & 225 & 4,5 & 142 & 3164 \\
\hline
\end{tabular}

Процент распустившихся глазков показывает способность сорта переносить неблагоприятные условия зимнего периода. За период исследований абсолютный минимум температуры воздуха составил минус $24,5{ }^{\circ} \mathrm{C}$ (8 января 2015 г.). Сохранность глазков в укрывном валу у изучаемых сортов винограда была хорошая. По методике М.А. Лазаревского, сорт Косоротовский имеет среднюю зимостойкость (3 балла, 60-40 \% живых глазков), а сорт Пухляковский - повышенную (4 балла, 80-60 \% живых глазков). 
Ранее проведенные наши исследования показали, что наблюдается положительная корреляция урожайности с минимальной температурой зимы. Фактором, лимитирующим урожайность в условиях Ростовской области, является температура. Наблюдающийся рост урожайности и средней массы грозди у большинства исследованных коллекционных сортов винограда вызван ростом температур периода активной вегетации и более мягкими условиями перезимовки. При сравнении урожайности с другими агробиологическими показателями было установлено, что, наиболее вариабельным признаком у всех сортов была урожайность, а самый стабильный признак - средняя масса ягоды [24].

При расчете урожайности важной составляющей является масса грозди. Средняя масса грозди у сорта Косоротовский выше, чем у контроля и варьировала по годам от 233 г до 358 г, у сорта Пухляковский - от 184 до 312 г.

Несмотря на то, что у сорта Косоротовский коэффициент плодоношения немного ниже, чем у сорта Пухляковский, при одинаковой нагрузке побегами (25 побегов на куст) урожайность у него выше.

По количеству дней от начала распускания почек до полной зрелости ягод сорта относятся к среднему сроку созревания, что благоприятно влияет на накопление достаточного количества сахаров, кислот и ароматических веществ.

Во второй декаде сентября оба сорта накапливают сахаров более 20 г/100 $\mathrm{cm}^{3}$ (табл. 2) при титруемой кислотности сока ягод от 6 до 8 г/дм³. Содержание сахаров в соке ягод соответствует требованиям ГОСТ, предъявляемым к сырью (не менее 16 г/100 см³ для белых столовых вин).

Проведение механического анализа сорта Косоротовский позволило установить содержание в процентах к массе грозди: сока 77,7; гребней 3,3; выжимок 15,0; семян 4,0; сахаристость сока ягод была 19,7 г/100 см³ при титруемой кислотности 7,7 г/дм³. 
Размерные характеристики грозди и средняя масса ягоды у сорта Косоротовский немного больше по сравнению с контролем. Более крупные грозди у технических сортов винограда являются положительным признаком.

Таблица 2 - Увологическая характеристика сортов винограда (среднее за 2015-2020 гг.)

\begin{tabular}{|c|c|c|c|c|c|c|c|c|}
\hline \multirow{2}{*}{$\begin{array}{c}\text { Название } \\
\text { сорта }\end{array}$} & \multicolumn{2}{|c|}{$\begin{array}{l}\text { Размеры } \\
\text { грозди, см }\end{array}$} & \multicolumn{2}{|c|}{$\begin{array}{c}\text { Размеры } \\
\text { ягоды, мм }\end{array}$} & \multirow{2}{*}{$\begin{array}{c}\text { Средняя } \\
\text { масса } \\
\text { ягоды, } \\
\text { г }\end{array}$} & \multirow{2}{*}{$\begin{array}{c}\text { Дата } \\
\text { анализа }\end{array}$} & \multicolumn{2}{|c|}{$\begin{array}{c}\text { Массовая } \\
\text { концентрация, } \\
\text { г/дм } \\
\end{array}$} \\
\hline & длина & ширина & длина & ширина & & & сахаров & $\begin{array}{c}\text { титруемых } \\
\text { кислот }\end{array}$ \\
\hline Косоротовский & 16,8 & 9,7 & 18,4 & 16,3 & 3,3 & 15.09 & 202 & 7,5 \\
\hline Пухляковский & 15,1 & 8,6 & 19,7 & 15,9 & 3,1 & 19.09 & 223 & 6,7 \\
\hline
\end{tabular}

Для проведения технологической оценки сортов, в лаборатории технологии виноделия были приготовлены столовые сухие белые вина. Качество сырья соответствовало требованиям ГОСТ. Заключительным этапом сортоизучения являлась органолептическая оценка вина. Оценка вин проводилась на закрытой научной дегустации дегустационной комиссией института, утвержденной приказом директора.

Сорт Косоротовский технологичен, быстро осветляется, не требует дополнительных приемов при переработке. Вино прозрачное, с блеском, соломенного цвета с зеленоватым оттенком. Аромат чистый, достаточно сформировавшийся, с легкими цветочно-фруктовыми тонами. Вкус гармоничный, полный.

Вино из сорта Пухляковский прозрачное, бледно-соломенного цвета, с зеленоватым оттенком. Богатый аромат с тонами полевых трав и цветов, переходящий во вкус. Долгое, приятное послевкусие.

Дегустационные оценки вин у изучаемых сортов по годам варьировали от 8,5 до 8,8 балла, средняя оценка у обоих сортов составила 8,6 балла.

Молекулярно-генетический паспорт сорта Косоротовский был сделан в ЦКП «Геномные и постгеномные технологии» (СКФНЦСВВ, 
г. Краснодар) по 6 микросателлитным локусам: VVS2 132/132, VVMD7 240/248, VVMD27 179/185, VVMD5 248/248, VrZAG62 188/204, VrZAG79 252/252.

Выводы. По результатам проведенного изучения агробиологических, технологических, увологических и хозяйственно-ценных свойств сорт Косоротовский не уступает контрольному сорту Пухляковский и может быть рекомендован для включения в сортимент виноградных насаждений Нижнего Придонья. Рекомендуется также использовать этот сорт в селекции для генетического улучшения белых технических сортов винограда как источник ценных хозяйственно-биологических и технологических свойств для высококачественного виноделия.

\section{Литература}

1. Ампелография аборигенных и местных сортов винограда Крыма: монография / В.В. Лиховской [и др.]. Симферополь: ООО «Форма», 2018. 140 с.

2. Трошин Л.П., Волынкин В.А., Клименко В.П. и др. Стратегия селекции винограда в ИВиВ «Магарач» // Виноград и вино России. 1994. № 5. С. 24-27.

3. Аборигенные сорта винограда Дагестана как генофонд для селекции новых сортов/ А.М. Аджиев [и др.] // Мобилизация и сохранение генетических ресурсов винограда, совершенствование методов селекционного процесса. Новочеркасск, 2008. C. $10-13$.

4. Volynkin V., Polulyah A. Origin of grapevine varieties in Crimea and Vitis vinifera subsp. silvestris classification // Vitis. 2015. V.54 (Special issue). P. 227-228.

5. Негруль А.М., Кац Я.Ф. История ампелографических исследований. Ампелографические исследования в СССР // Ампелография СССР. Т. 1. М.: Пищепромиздат, 1946. C. $27-44$.

6. Алиев А.М., Кравченко Л.В., Наумова Л.Г., Ганич В.А. Донские аборигенные сорта винограда. 2-е изд., перераб. и доп. Новочеркасск, 2013. 131 с.

7. Лукьянов А.Д. Виноградарство на Дону // Донское виноградарство. Ростов-на-Дону: Ростовское областное книгоиздательство, 1939. С. 5-47.

8. Потапенко А.И. Старожил земли русской. Ростов-на-Дону: Ростовское книжное изд-во, $1976.96 \mathrm{c.}$

9. Потапенко А.И. О происхождении донских сортов винограда // Русский виноград. 1972. № 4(13). С. 14-24.

10. Halász G., Veres A., Kozma P. et al. Microsatellite fingerprinting of grapevine (Vitis vinifera L.) varieties of the Carpathian Basin. Vitis. 2005;44(4):173-180.

11. This P., Jung A., Boccacci P. et al. Development of a standard set of microsatellite reference alleles for identification of grape cultivars. Theor. Appl. Genet. 2004;(109): 1448-1458. DOI:10.1007/s00122-004-1760-3.

12. Martinez L.E, Cavagnaro P.F, Masuelli R.W, Zuniga M. SSR-based assessment of genetic diversity in South American Vitis vinifera varieties. Plant Sci. 2006;(170):1036-1044. 
13. Karatas H., Degirmenci D., Velasco R. et al. Microsatellite fingerprinting of homonymous grapevine (Vitis vinifera L.) varieties in neighboring regions of South-East Turkey. Scientia Horticulturae. 2007;(114):164-169. DOI 10.1016/j. scienta.2007.07.001.

14. Stajneri N, Korosec-Korusa Z, Rusjan D, Javornic B. Microsatellite genotyping of old Slovenian grapevine varieties (Vitis vinifera L.) of the Primorje (coastal) winegrowing region. Vitis. 2008;47(4):201-204.

15. Dzhambazova T., Tsvetkov I., Atanassov I. et al. Genetic diversity in native Bulgarian grapevine germplasm (Vitis vinifera L.) based on nuclear and chloroplast microsatellite polymorphisms. Vitis. 2009;48(3):115-121.

16. Boz Y., Bakir M., Çelikkol B.P. et al. Genetic characterization of grape (Vitis vinifera L.) germplasm from Southeast Anatolia by SSR-markers. Vitis. 2011;50(3):99-106.

17. Guo DL, Zhang Q, Zhang GH. Characterization of grape cultivars from China using microsatellite markers. Czech J. Genet. Plant Breed. 2013;(49):164-170.

18. Basheer-Salimia R., Lorenzi S., Batarseh F. et al. Molecular identification and genetic relationships of Palestinian grapevine cultivars. Molecular biotechnology. 2014;56(6):546-556.

19. Maul E., Töpfer R., Carka F. et al. Identification and characterization of grapevine genetic resources maintained in eastern european collections. Vitis, 2015,54(1):5-12.

20. Рисованная В.И. Изменчивость столовых и технических сортов $V$. vinifera L. западноевропейской и восточной эколого-географических групп по аллозимным локусам // Магарач. Виноградарство и виноделие. 2010. № 1. С. 2-5.

21. Милованов А.В., Ильницкая Е.Т., Радченко В.В. и др. Сравнительный анализ аллельного состояния локуса VVMYBA1 у некоторых аборигенных и интродуцированных сортов винограда // Сельскохозяйственная биология. 2020. Т. 55. № 3. C. 523-532. DOI: 10.15389/agrobiology.2020.3.523rus

22. Елецкий В.В., Лазаревский М.А. Косоротовский // Ампелография СССР. Т. 3. М.: Пищепромиздат, 1954. С. 321-330.

23. Изучение генетического сходства донских аборигенных сортов винограда с применением SSR-анализа и по основным ампелографическим признакам листа / Е.Т. Ильницкая [и др.] // Сельскохозяйственная биология. 2016. Т. 51. № 1. С. 60-67. DOI: 10.15389/agrobiology.2016.1.60rus

24. Наумова Л.Г., Новикова Л.Ю. Анализ тенденций изменения урожайности сортов винограда коллекции ВНИИВиВ им. Я.И. Потапенко // Виноделие и виноградарство. 2014. № 5. С. 44-49.

\section{Reference}

1. Ampelografiya aborigennyh i mestnyh sortov vinograda Kryma: monografiya / V.V. Lihovskoj [i dr.]. Simferopol': OOO «Forma», 2018. 140 s.

2. Troshin L.P., Volynkin V.A., Klimenko V.P. i dr. Strategiya selekcii vinograda v IViV «Magarach» // Vinograd i vino Rossii. 1994. № 5. S. 24-27.

3. Aborigennye sorta vinograda Dagestana kak genofond dlya selekcii novyh sortov/ A.M. Adzhiev [i dr.] // Mobilizaciya i sohranenie geneticheskih resursov vinograda, sovershenstvovanie metodov selekcionnogo processa. Novocherkassk, 2008. S. 10-13.

4. Volynkin V., Polulyah A. Origin of grapevine varieties in Crimea and Vitis vinifera subsp. silvestris classification // Vitis. 2015. V.54 (Special issue). P. 227-228.

5. Negrul' A.M., Kac Ya.F. Istoriya ampelograficheskih issledovanij. Ampelograficheskie issledovaniya v SSSR // Ampelografiya SSSR. T. 1. M.: Pishchepromizdat, 1946. S. 27-44.

6. Aliev A.M., Kravchenko L.V., Naumova L.G., Ganich V.A. Donskie aborigennye sorta vinograda. 2-e izd., pererab. i dop. Novocherkassk, 2013. 131 s. 
7. Luk'yanov A.D. Vinogradarstvo na Donu // Donskoe vinogradarstvo. Rostov-na-Donu: Rostovskoe oblastnoe knigoizdatel'stvo, 1939. S. 5-47.

8. Potapenko A.I. Starozhil zemli russkoj. Rostov-na-Donu: Rostovskoe knizhnoe izd-vo, 1976. $96 \mathrm{c.}$

9. Potapenko A.I. O proiskhozhdenii donskih sortov vinograda // Russkij vinograd. 1972. № 4(13). S. 14-24.

10. Halász G., Veres A., Kozma P. et al. Microsatellite fingerprinting of grapevine (Vitis vinifera L.) varieties of the Carpathian Basin. Vitis. 2005;44(4):173-180.

11. This P., Jung A., Boccacci P. et al. Development of a standard set of microsatellite reference alleles for identification of grape cultivars. Theor. Appl. Genet. 2004;(109): 1448-1458. DOI:10.1007/s00122-004-1760-3.

12. Martinez L.E, Cavagnaro P.F, Masuelli R.W, Zuniga M. SSR-based assessment of genetic diversity in South American Vitis vinifera varieties. Plant Sci. 2006;(170):1036-1044.

13. Karatas H., Degirmenci D., Velasco R. et al. Microsatellite fingerprinting of homonymous grapevine (Vitis vinifera L.) varieties in neighboring regions of South-East Turkey. Scientia Horticulturae. 2007;(114):164-169. DOI 10.1016/j. scienta.2007.07.001.

14. Stajneri N, Korosec-Korusa Z, Rusjan D, Javornic B. Microsatellite genotyping of old Slovenian grapevine varieties (Vitis vinifera L.) of the Primorje (coastal) winegrowing region. Vitis. 2008;47(4):201-204.

15. Dzhambazova T., Tsvetkov I., Atanassov I. et al. Genetic diversity in native Bulgarian grapevine germplasm (Vitis vinifera $\mathrm{L}$.) based on nuclear and chloroplast microsatellite polymorphisms. Vitis. 2009;48(3):115-121.

16. Boz Y., Bakir M., Çelikkol B.P. et al. Genetic characterization of grape (Vitis vinifera L.) germplasm from Southeast Anatolia by SSR-markers. Vitis. 2011;50(3):99-106.

17. Guo DL, Zhang Q, Zhang GH. Characterization of grape cultivars from China using microsatellite markers. Czech J. Genet. Plant Breed. 2013;(49):164-170.

18. Basheer-Salimia R., Lorenzi S., Batarseh F. et al. Molecular identification and genetic relationships of Palestinian grapevine cultivars. Molecular biotechnology. 2014;56(6):546-556.

19. Maul E., Töpfer R., Carka F. et al. Identification and characterization of grapevine genetic resources maintained in eastern european collections. Vitis, 2015,54(1):5-12.

20. Risovannaya V.I. Izmenchivost' stolovyh i tekhnicheskih sortov V. vinifera L. zapadnoevropejskoj i vostochnoj ekologo-geograficheskih grupp po allozimnym lokusam // Magarach. Vinogradarstvo i vinodelie. 2010. № 1. S. 2-5.

21. Milovanov A.V., Il'nickaya E.T., Radchenko V.V. i dr. Sravnitel'nyj analiz allel'nogo sostoyaniya lokusa VVMYBA1 u nekotoryh aborigennyh i introducirovannyh sortov vinograda // Sel'skohozyajstvennaya biologiya. 2020. T. 55. № 3. S. 523-532. DOI: 10.15389/agrobiology.2020.3.523rus

22. Eleckij V.V., Lazarevskij M.A. Kosorotovskij // Ampelografiya SSSR. T. 3. M.: Pishchepromizdat, 1954. S. 321-330.

23. . Izuchenie geneticheskogo skhodstva donskih aborigennyh sortov vinograda $\mathrm{s}$ primeneniem SSR-analiza i po osnovnym ampelograficheskim priznakam lista / E.T. Il'nickaya [i dr.] // Sel'skohozyajstvennaya biologiya. 2016. T. 51. № 1. S. 60-67. DOI: 10.15389/agrobiology.2016.1.60rus

24. Naumova L.G., Novikova L.Yu. Analiz tendencij izmeneniya urozhajnosti sortov vinograda kollekcii VNIIViV im. Ya.I. Potapenko // Vinodelie i vinogradarstvo. 2014. № 5. S. 44-49. 